\title{
BIBLIOGRAPHY.
}

Adler. Ein Fall v. selt. Cornealaffektion, Wien. med. Wochenschr., 1891, p. 704.

American Encyclopedia of Ophthalmology, pp. 3436 and 5631.

Axenfeld. The Bacteriology of the Eye, Translated by Macnab, 1908, p. 320.

Bajardi. Un caso di granuloma della cornea, Thèse de Lyon, quoted after Nagel's Jahresbericht u. Ophthalmologie, 1905, p. 273.

Bajardi. Un caso di granuloma della cornea Gior. d. r. Accad. di med. di Torino, 1900, p. 452, quoted after Nagel's Jahresbericht u. Ophth almologie, 1900, p. 222.

Beierle. Wucherung i. Aug. eines Hundes, Monatsch. f. Thierheilk. 4, 273, quoted after Nagel's Jahresbericht u. Ophthalmologie, 1893, p. 546.

von Blaskovics. D. Geschwülste d. Hornhaut, Ungar. Beiträge z. Augenh., ed. W. Schulek, $1900,2,131$.

Bock. Allg. Wien. med. Ztg., 1883, Nos. 40-43; 1892, No. 22, quoted by Blaskovics.

Desmarres. Traité d. mal. d. yeux, 2, 321, quoted by Lewin and Guillery, p. 769.

Gay. Tumeur de la cornée chez une chienne, Bull. d. l. soc. des sc. vétér. d. Lyon, 5,45 , quoted after Nagel's Jahresbericht u. Ophthalmologie, 1902, p. 735.

Gosart. Quoted by Lewin and Guillery, p. 770.

Hirschberg and Ginsberg. Ein selt. Fall v. Hornhaut-Geschwulst, Centraibl. f. prakt. Augenh., 1905, p. 33.

Jackson." Tr. Sect. Ophth., A. M. A. 1916, p. 67.

Lawson. A Case of Cicatrix Horn Growing from the Cornea, Tr. Ophth. Soc. U. Kingdom, 1900, p. 73.

Lagrange. Traité des tumeurs de loeil, 1901, 1, 195.

Lewin und Guillery. D. Wirkungen v. Arzneimitteln u. Giften auf d. Auge, 1913, 2nd edit. vol. 2 .

Mallory. The Principles of Pathologic Histology, 1914, pp. 71, 72.

Pagenstecher and Genth. Atlas d. patholog. A natomie d. Augapfels, 1875, Plate 12.

Parsons. Pathology of the Eye, 1904, 1. p. 169, 264, 265.

Raabe. Beiträge zur patholog. Anatomie d. aeusseren Augenerkrankungen, Inaug. Dissert, Marburg, 1893, quoted after Nagel's Jahresbericht u. Ophthalmologie, 1893, p. 189.

Reishaus. Beitrag zur Aetiologie der Cornea-Fibrome, Beitr, z. Augenh., 1899, 4, 100-111.

Schaeche. Ueber citr. Panophthalmitis u. Kalkveraetz. Freiberg, 1889, quoted by Lewin and Guillery, p. 773

Echmidt-Rimpler. Ueber Kalkverletz. d. Aug., Rerl, klin. Wochenschr., 1900, No. 36, p. 789.

Sichel. Iconographie ophthalmologique, 1852-1859, Plate 58.

Stellwag. Die Ophthalmologie v. naturw. Standp., 1, 347, quoted after Lagrange.

Weeks. Tr. Sect. Ophth., A. M. A. 1916, p. 67.

Wintersteiner. Encykloped. d. Augenheilkunde, ed. O. Schwarz, 1902, p. 386.

Zirm. Eine eigenth. oberfl. Neubild. d. Corn., A rch. f. Ophth. 1891, 37, 253.

Pajardi. Un caso di granuloma della cornea. This report is of a collective investigation

\section{OPHTHALMO - THERAPEUTIC IGNORANCE REGARDING OPTIC ATROPHIES.}

Mark J. Schoenberg, M. D.

NEW YORK.

This report is of a collective investigation regarding the current treatment of optic nerve atrophies among American ophthalmologists.

During the past few years the therapeutics of neurosyphilis has been enriched by the addition of one new drug and a new method of medication: salvarsan and intraspinal or intracranial injections.

Knowing the disappointing results obtained by ophthalmologists by their old routine method (mercury, iodids and strychnin), in treating syphilitic optic atrophies I made the attempt a few years ago to obtain a general idea about their expcrience and attitude regarding the treatment of this condi- tion since the introduction of the salvarsan and spinal medication. I sent letters* of inquiry to several hundred

*With this occasion I wish to express my thanks for their frank and prompt reply. I am fully aware of the fact that we have to be very cautious in drawing conclusions from replies coming from an extreme variety of sources. But nobody can deny that an investigation of this sort shows us the general consensus of opinion and gives us a fair idea of how little 200 of the foremost men engaged in this specialty feel that they can accomplish with the present means of treating atrophic conditions of luetic nature of the vistual pathways. 
colleagues and received over 200 replies from ophthalmologists of large experience from all over the country.

(1) Are you obtaining better results in the treatment of progressive optic atrophy of luetic nature since the addition of salvarsan to our therapeutics?

To this question 56 ophthalmologists answered that they never used salvarsan; 106 , that the results are worse or indifferent; 24 regard with favor the use of intravenous injections of salvarsan, but add that their experience is very limited.

(2) Do you use intraspinal injections in luetic atrophies? What results?

To this question 139 answered that they never used spinal injections; 4 , that their experience is too limited to give any opinion; 23 , that they have used this method with no success; 17 rave used the spinal treatment in 1 or 2 cases and were favorably impressed.

As we see, the majority was unfavorably inclined towards the intravenous administration of salvarsan. As for the spinal treatment the state of affairs is still gloomier: The method had not even been given a trial by most cphthalmologists.

This investigation will surely raise in the minds of the readers a number of objections and comments. Nothing can be answered to the objection (if they have any) of those who never tried salvarsan under any form or method. No definite conclusion can be drawn even from the statement of those who say that the results (in cases treated by intravenous salvarsan injections) are indifferent or bad, be cause: (a) In the replies received the confusion is frequently made between the neuritic and taboparetic type of cptic atrophies; (b) Nothing is mentioned about the dosage and total amount of salvarsan, frequency of administration, duration of treatment, etc. Many have given up the treatment after 1 or 2 injections, which does not prove anything.

Regarding the lack of experience with the intraspinal treatment of 143 out of 183 ophthalmologists we have the impression that it is due to the fact that this method is considered by our confréres either very difficult, dangerouts or ineffective. The question of efficacy of spinal treatment and intravenous injections of salvarsan will be discussed more fully in another paper. The statement of those who have used the spinal treatment without beneficial results cannot be accepted as first class evidence, because we are not furnished with results regarding the condition of the patients and how systematically the treatment had been carried out.

The writer knows of cases which have been given up because one or two spinal injections have failed to improve the vision, or because vision continued to fail after the first injection. These cases and such treatment do not prove anything. An arrest of the process causing the failing vision or even an improvement should be expected only after a systematic course of 6 to 12 or more spinal treatments have been administered, combined with a general cautious but persistent antiluetic treatment. It is superfluous to add that the technic of spinal puncture is not very difficult, nor is it dangerous if done with care. The tens of thousands of spinal punctures done with impunity in this country and abroad prove my contention.

Among the questions and suggesticns contained in the replies to my circular letter the following ones deserve to be mentioned:

1. Many ophthalmologists are of the opinion that salvarsan acts injuriously upon the optic nerves which are in the process of atrophy; others believe to the contrary, that it is more injurious in nonluetic atrophies; and still others think that salvarsan may cause atrophy in perfectly intact optic nerves: Since these opinions are in part based on hearsay and in part upon a post hoc propter hoc occurrence, we have no right to accept them as facts. Time and accurate observations will clear up this point. To those who have used a great deal of salvarsan in syphilis of the central nervous system one thing is clear, namely, that it is not injurious to the healthy or damaged optic nerves, if 
administered in proper doses and at proper intervals.

2. Some express their belief that the drug is beneficial only in incipient cases of optic atrophies. Experience shows that this is true only in some cases. I have seen patients with a moderately advanced optic atrophy greatly benefited by spinal and general treatment.

3 . Some, notwithstanding the numerous reports in neurologic literature, consider the spinal treatment as a dangerous procedure. My own experience is opposite to their belief. I have never seen one single case in which I had reascn to regret the use of the spinal method of treatment, and Dr. I. Rosen, Chief of the Department of Syphilis of the Vanderbilt Clinic, who has given several thousands of injections, never had a single accident.

4. A few gentlemen from Philadelphia have based their doubts on the value of salvarsan in optic atrophies upon the supposition, almost universally accepted, that the drug is a spirochetecide and not an antidegenerative. While this objection seems to be quite right, we must not forget that there is still a possibility that the action of salvarsan mav not be directed only upon the spirochetae, but may (as I think very probable), act upon the tissues as a stimulant as well. Furthermore, it is a fact that there are cases of optic atrophies in which the process was arrested by the systematic and judicious treatment with salvarsan and mercury. 5. How much should we fear a Herxheimer reaction while treating lues of the optic nerves, is a question brought up by a few colleagues. A very well known and highly reputed ophthalmologist does not use the salvarsan on account of a possibility of setting up a reaction in the optic nerves of sufficient intensity to cause a permanent damage to the nerve fibers. This fear, very current at the beginning of the salvarsan era, has gradually subsided now, when we use much smaller initial doses preceded by $\mathrm{Hg}$. intramuscularly.
6. One colleague calls my attention to the fact that in some patients with chronic or latent nasal sinusitis the condition may become acute under the influence of salvarsan; and thus act tipon the optic nerves-a sort of Herxheimer reaction in the nasal sinuses.

7. Finally, a large number of ophthalmologists, many of them among our leaders, flatly declare that their expcrience with the treatment of luetic cptic atrophy is limited, because they refer their cases, where they belong; some to neurologists, others to syphilographers. It is undoubtedly correct to have the patient examined by a trained neurologist, because the patient has, most of the time, syphilis of the entire central nervous system, not anly of the optic pathways. It is probably advisable to put the patient in the liands of a syphilographer experienced in the treatment of neurosyphilis; but it is unfortunate to throw him overtoard and let the neurologist or syphilographer take entire charge of him. We have only to read up the reports on cases of neurosyphilis with eye manifestations, and, no matter who the author is (be he a leading syphilographer or neurologist), we will be surprised by the lack of completeness of and interest in the ophthalmologic phase of these reports.

Reliable ophthalmoscopic examinations, fields of vision, measuring of the acuity of vision, etc., can be made only by ophthalmologists; their special interest in the visual organ makes them more fit to judge of the progress obtained and more concerned about the outcome of the entire case. I should consider as ideal to have the ophthalmologist administer the treatment, and have the neurologist and syphilographer act only in advisory capacity. This would give him more experience on the neurologic end of the subject, and would stimulate him to try again to find a better way of treating syphilitic involvement of the optic pathways. 